\title{
Efficient catalytic alkyne metathesis with a fluoroalkoxy-supported ditungsten(III) complex
}

\author{
Henrike Ehrhorn, Janin Schlösser, Dirk Bockfeld and Matthias Tamm*
}

\author{
Full Research Paper \\ Address: \\ Institut für Anorganische und Analytische Chemie, Technische \\ Universität Braunschweig, Hagenring 30, 38106 Braunschweig, \\ Germany \\ Email: \\ Matthias Tamm* - m.tamm@tu-bs.de \\ * Corresponding author \\ Keywords: \\ alkylidyne complexes; alkyne metathesis; catalysis; terminal alkynes; \\ tungsten
}

\author{
Beilstein J. Org. Chem. 2018, 14, 2425-2434. \\ doi:10.3762/bjoc. 14.220 \\ Received: 25 June 2018 \\ Accepted: 27 August 2018 \\ Published: 18 September 2018 \\ This article is part of the thematic issue "Progress in metathesis chemistry \\ III". \\ Guest Editor: K. Grela \\ (C) 2018 Ehrhorn et al.; licensee Beilstein-Institut. \\ License and terms: see end of document.
}

\begin{abstract}
The molybdenum and tungsten complexes $\mathrm{M}_{2}(\mathrm{OR})_{6}\left(\mathbf{M o 2 F 6}, \mathrm{M}=\mathrm{Mo}, \mathrm{R}=\mathrm{C}\left(\mathrm{CF}_{3}\right)_{2} \mathrm{Me}\right.$; W2F3, $\left.\mathrm{M}=\mathrm{W}, \mathrm{R}=\mathrm{OC}\left(\mathrm{CF}_{3}\right) \mathrm{Me}_{2}\right)$ were synthesized as bimetallic congeners of the highly active alkyne metathesis catalysts $\left[\mathrm{MesC} \equiv \mathrm{M}\left\{\mathrm{OC}\left(\mathrm{CF}_{3}\right)_{n} \mathrm{Me}_{3-n}\right\}\right](\mathbf{M o F}$, $\mathrm{M}=\mathrm{Mo}, n=2 ; \mathbf{W F 3}, \mathrm{M}=\mathrm{W}, n=1 ; \mathrm{Mes}=2,4,6$-trimethylphenyl). The corresponding benzylidyne complex $\left[\mathrm{PhC} \equiv \mathrm{W}\left\{\mathrm{OC}\left(\mathrm{CF}_{3}\right) \mathrm{Me}_{2}\right\}\right]\left(\mathbf{W}^{\mathbf{P h}} \mathbf{F 3}\right)$ was prepared by cleaving the $\mathrm{W} \equiv \mathrm{W}$ bond in $\mathbf{W} 2 \mathbf{F 3}$ with 1-phenyl-1-propyne. The catalytic alkyne metathesis activity of these metal complexes was determined in the self-metathesis, ring-closing alkyne metathesis and cross-metathesis of internal and terminal alkynes, revealing an almost equally high metathesis activity for the bimetallic tungsten complex W2F3 and the alkylidyne complex $\mathbf{W}^{\mathbf{P h}} \mathbf{F 3}$. In contrast, Mo2F6 displayed no significant activity in alkyne metathesis.
\end{abstract}

\section{Introduction}

While the field of olefin metathesis has seen significant progress in the past decades [1-5], the synthetic potential of alkyne metathesis has been growing only recently [6-11]. Alkyne metathesis represents a transition-metal-catalyzed transformation in which carbon-carbon triple bonds are cleaved and formed under mild conditions via metallacyclobutadiene (MCBD) intermediates [12]. Ongoing progress in the development of highly active homogeneous alkyne metathesis catalysts (Figure 1) has increased the value of this method in natural product and materials chemistry.
The contributions from our group to the development of alkyne metathesis catalysts were initially based on a design strategy inspired by the structure of highly active olefin metathesis catalysts, the Schrock-type molybdenum and tungsten alkylidene complexes [13-15]. Imidazolin-2-iminato ligands were used to modify Schrock-type alkylidyne complexes, resulting in new active alkyne metathesis catalysts such as I (Figure 1) [16-20]. Initially, the neopentylidyne tungsten complex was synthesized via the conventional "high-oxidation-state route" developed by R. R. Schrock $[16,17,21,22]$; later, the "low-oxidation-state 


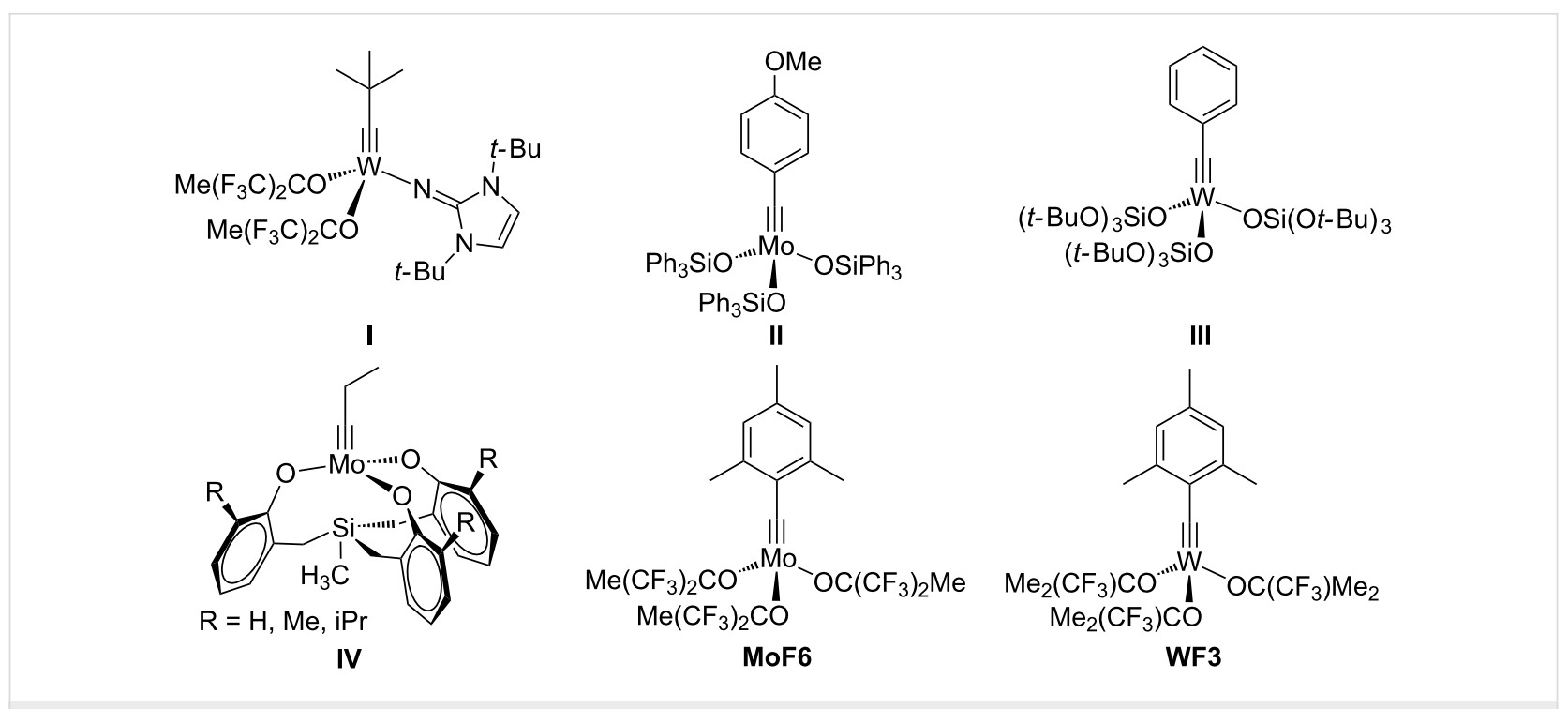

Figure 1: Selected homogeneous catalysts for alkyne metathesis

route", starting from $\mathrm{M}(\mathrm{CO})_{6}(\mathrm{M}=\mathrm{Mo}, \mathrm{W})$, was employed, which gave rise to the corresponding molybdenum and tungsten benzylidyne complexes [18-20].

In addition to these, several well-defined alkylidyne complexes have been developed and successfully utilized in alkyne metathesis in the past decade. The molybdenum alkylidyne complex with triphenylsiloxide ligands (type II) introduced by A. Fürstner and co-workers is frequently used in the total synthesis of natural products [23-27]. A unique catalytic reactivity towards conjugated diynes was observed for the tungsten benzylidyne complex with $\mathrm{OSi}(\mathrm{O} t-\mathrm{Bu})_{3}$ ligands (type III) [2830]. The catalyst III, which is capable of promoting conventional alkyne metathesis [19], also proved to be highly active in the cross metathesis of symmetric 1,3-butadiynes to form unsymmetrically substituted 1,3-butadiynes [30]. W. Zhang and his group introduced several multidentate phenoxide ligands to molybdenum propylidyne precursors to form chelate complexes of type IV [31-34]. These catalysts were especially successful in the construction of supramolecular materials such as ethynylene-linked polymers [11,35], porous networks [36] and molecular cages [37-43]. Furthermore, living ring-opening alkyne metathesis polymerization (ROAMP) has been intensely studied for different molybdenum alkylidyne complexes by the group of F. R. Fischer, who was able to monitor the influence of both the alkylidyne moiety as well as the ancillary ligands [4448].

More recently, we expanded the "low-oxidation-state route" to the synthesis of 2,4,6-trimethylbenzylidyne complexes of molybdenum and tungsten $[18,49,50]$, which led to an increased steric demand at the metal center. This proved to be ad- vantageous for the catalytic activity, since the removal of coordinating solvents like THF or DME was facilitated [49]. The molybdenum 2,4,6-trimethylbenzylidyne complex $\left[\mathrm{MesC} \equiv \mathrm{Mo}\left\{\mathrm{OC}\left(\mathrm{CF}_{3}\right)_{2} \mathrm{Me}\right\}_{3}\right]$ (Figure 1, MoF6) represents the first alkyne metathesis catalyst capable of effective and highly selective terminal alkyne metathesis [49,51-53]. Later, a study was conducted to determine the optimum degree of fluorination of the alkoxide ligands for tungsten alkylidyne complexes $[53,54]$. It was found that the tungsten alkylidyne complex $\left[\mathrm{MesC} \equiv \mathrm{W}\left\{\mathrm{OC}\left(\mathrm{CF}_{3}\right) \mathrm{Me}_{2}\right\}_{3}\right]$ (Figure 1, WF3) showed excellent catalytic performance not only in the metathesis of internal but also, for the first time with the metal tungsten, terminal alkynes at room temperature [54]. Our studies clearly display a strong dependency of the catalytic alkyne metathesis activity on the metal-alkoxide combination. The electrophilicity of the metal sites can be controlled by the number of fluorine atoms of the ancillary fluoroalkoxide ligands [55-57]. The difference in the optimum degree of fluorination for molybdenum and tungsten is rationalized by the increased intrinsic electrophilicity of tungsten compared to molybdenum [56].

Based on these insights into the structure-activity relationship of alkyne metathesis catalysts, we wanted to establish an alternative and convenient access to highly active catalysts. Herein, we report the systematic study on the metathesis performance of bimetallic hexaalkoxide complexes $\mathrm{M}_{2}(\mathrm{OR})_{6}(\mathrm{M}=\mathrm{Mo}$, $\mathrm{R}=\mathrm{OC}\left(\mathrm{CF}_{3}\right)_{2} \mathrm{Me}$, Mo2F6; $\left.\mathrm{M}=\mathrm{W}, \mathrm{R}=\mathrm{OC}\left(\mathrm{CF}_{3}\right) \mathrm{Me}_{2}, \mathbf{W 2 F 3}\right)$, which draw upon the most catalytically active alkylidyne complexes MoF6 and WF3. R. R. Schrock synthesized the first alkylidyne complex which was able to undergo alkyne metathesis, $\left[t-\mathrm{BuC} \equiv \mathrm{W}(\mathrm{O} t-\mathrm{Bu})_{3}\right](\mathbf{V})$, originally from $\left[\mathrm{NEt}_{4}\right][t$ $\left.\mathrm{BuC} \equiv \mathrm{WCl}_{4}\right][22,58-61]$. Subsequently, he reported a protocol 
to synthesize the alkylidyne complex $\mathbf{V}$ by a stoichiometric alkyne metathesis reaction of the ditungsten complex $\left[(t-\mathrm{BuO})_{3} \mathrm{~W} \equiv \mathrm{W}(\mathrm{O} t-\mathrm{Bu})_{3}\right]$ with $\mathrm{MeC} \equiv \mathrm{C} t-\mathrm{Bu}$ (Scheme 1) [62] Even though Schrock's catalyst $\mathbf{V}$ was the most established alkyne metathesis catalyst for many years [63,64], it does not promote terminal alkyne metathesis efficiently and leads to polymerization initiated by intermediate deprotiometallacyclobutadiene species [55,60,61,65-67]. Moreover, the bimetallic $\left[(t-\mathrm{BuO})_{3} \mathrm{~W} \equiv \mathrm{W}(\mathrm{O} t-\mathrm{Bu})_{3}\right]$ complex has not been directly employed in catalytic alkyne metathesis.
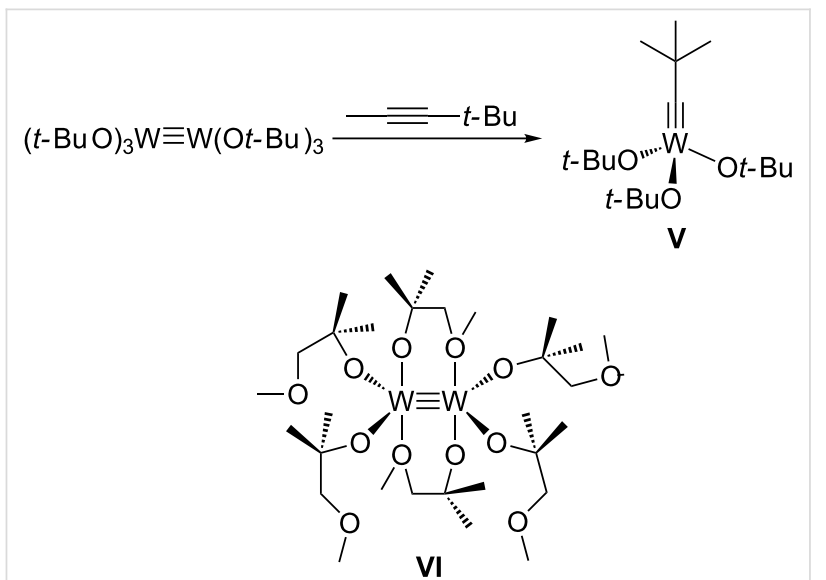

Scheme 1: Synthesis of alkylidyne complex $\mathbf{V}$ from bimetallic $\left[(t-\mathrm{BuO})_{3} \mathrm{~W} \equiv \mathrm{W}(\mathrm{O} t-\mathrm{Bu})_{3}\right]$; the catalytically active ditungsten complex $\left[\mathrm{W}_{2}(\mathrm{MMPO})_{6}\right](\mathrm{VI}, \mathrm{MMPO}=1$-methoxy-2-methylpropan-2-ol) [68].

A. Mortreux and his group found that the alkyne metathesis selectivity of Schrock's original catalyst $\mathbf{V}$ can be enhanced by adding an external ligand like quinuclidine to the reaction mix- ture [61]. Thereby, the self-metathesis yield of 1-heptyne could be increased to $80 \%$ at elevated temperatures. Based on this approach, the dinuclear tungsten complex $\left[\mathrm{W}_{2}(\mathrm{MMPO})_{6}\right]$ (VI, MMPO = 1-methoxy-2-methylpropan-2-ol) was isolated which catalyzed alkyne metathesis of 1-heptyne at elevated temperatures [68] and to date represents the only well-defined ditungsten complex which has been successfully used in alkyne metathesis.

The organometallic chemistry of the $\mathrm{M}_{2} \mathrm{X}_{6}$ complexes $(\mathrm{X}=\mathrm{R}$ (alkyl), $\mathrm{NR}_{2}, \mathrm{OR}$ ) with metal-metal triple bonds ( $\left.\mathrm{M}=\mathrm{Mo}, \mathrm{W}\right)$ has attracted attention for many years (mainly during the $70 \mathrm{~s}$, $80 \mathrm{~s}$ and 90s) [69]. A plethora of dinuclear compounds has been published [70-78], and detailed studies on their reactivity have been conducted [79-85]. Therefore, the reactivity of ditungsten complexes towards alkynes has been known for quite some time. The metal-metal triple bond of many ditungsten complexes can be cleaved by alkynes in a metathesis-like reaction to form the corresponding alkylidyne complexes $[62,86]$. Dinuclear $\mathrm{Mo} \equiv$ Mo complexes, however, have not yet been cleaved efficiently by alkynes [87].

\section{Results and Discussion Complex synthesis}

The dimeric molybdenum complex $\left[\mathrm{Mo}_{2} \mathrm{Cl}_{6}(\mathrm{dme})_{2}\right]$ (dme $=1,2$-dimethoxyethane) serves as an excellent starting material for compounds of the type $\mathrm{Mo}_{2} \mathrm{X}_{6}(\mathrm{X}=$ alkyl, alkoxide) [73]. The desired hexakis(fluoroalkoxide) dimer $\left[\mathrm{Mo}_{2}\left\{\mathrm{OC}\left(\mathrm{CF}_{3}\right)_{2} \mathrm{Me}\right\}_{6}\right]$ (Mo2F6) was first isolated by D. Rogers and his group by salt metathesis of $\left[\mathrm{Mo}_{2} \mathrm{Cl}_{6}(\mathrm{dme})_{2}\right]$ with 6 equiv of $\mathrm{NaOC}\left(\mathrm{CF}_{3}\right)_{2} \mathrm{Me}$ (Scheme 2) [73]. This reaction

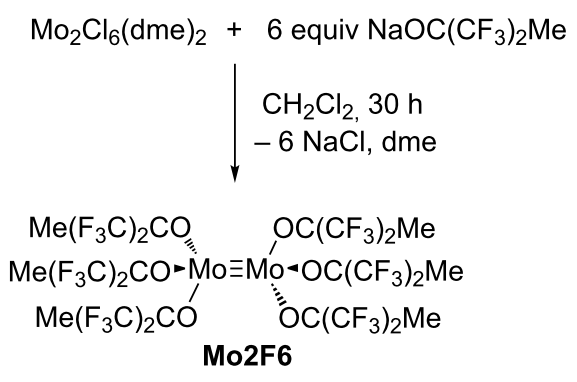

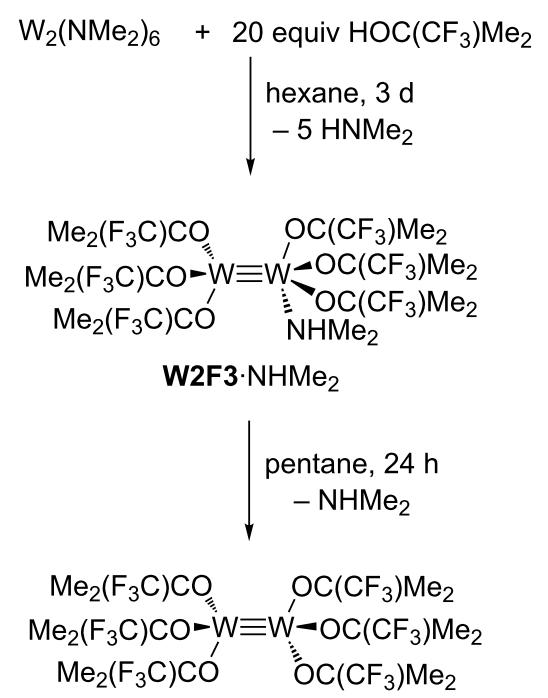


affords a red, sparingly soluble complex in moderate yield $(28 \%)$.

The bimetallic tungsten analogue to WF3, $\left[\mathrm{W}_{2}\left\{\mathrm{OC}\left(\mathrm{CF}_{3}\right) \mathrm{Me}_{2}\right\}_{6}\right]$ (W2F3), can be prepared by the reaction of $\left[\mathrm{NaW}_{2} \mathrm{Cl}_{7}(\mathrm{THF})_{5}\right]$ with 6 equiv of $\mathrm{NaOC}\left(\mathrm{CF}_{3}\right) \mathrm{Me}_{2}$ [86], but this procedure requires one equivalent of toxic sodium amalgam. Therefore, we decided to attempt the protonolysis of hexakis(dimethylamido)ditungsten $\left[\mathrm{W}_{2}\left(\mathrm{NMe}_{2}\right)_{6}\right]$ with the alcohol $\mathrm{HOC}\left(\mathrm{CF}_{3}\right) \mathrm{Me}_{2}[71,88]$, which has been described very briefly in the literature [89]. $\left[\mathrm{W}_{2}\left(\mathrm{NMe}_{2}\right)_{6}\right]$ is easily accessible from $\mathrm{WCl}_{4}$ and $\mathrm{LiNMe}_{2}$ and has emerged as an important starting material for various dinuclear tungsten compounds [90]. M. H. Chisholm and co-workers used 6 equiv of the free alcohol to exchange the amide ligands and isolated the bis(dimethylamino) adduct of the ditungsten complex [89]. The amine ligands were liberated under reduced pressure and at elevated temperature. However, in our hands, an excess of $\mathrm{HOC}\left(\mathrm{CF}_{3}\right) \mathrm{Me}_{2}$ was required to drive the reaction to completion and led to the formation of the complex $\left[\mathrm{W}_{2}\left\{\mathrm{OC}\left(\mathrm{CF}_{3}\right) \mathrm{Me}_{2}\right\}_{6}\left(\mathrm{NHMe}_{2}\right)\right]$ (W2F3 $\left.\cdot \mathrm{NHMe}_{2}\right)$ (Scheme 2). The additional amine ligand stems from the protonolysis reaction of the amide with the fluorinated alcohol. Brown crystals suitable for X-ray diffraction analysis were isolated from a saturated pentane solution at $-40{ }^{\circ} \mathrm{C}$. The molecular structure of this complex was established by $\mathrm{X}$-ray diffraction analysis. The ORTEP diagram is shown in Figure 2, and selected bond lengths and angles are displayed in Table 1.

The tungsten-tungsten triple bond of 2.3452(2) $\AA$ falls in the range of previously reported bond lengths of this type [69]. For example, the $\mathrm{W} \equiv \mathrm{W}$ distance in $\left[\mathrm{W}_{2}\left\{\mathrm{OC}\left(\mathrm{CF}_{3}\right)_{2} \mathrm{Me}\right\}\right]_{6}$ is 2.309(3) $\AA[78], 2.430(8) \AA$ in $\left[\mathrm{W}_{2}(\mathrm{MMPO})_{6}\right]$ [68], and $2.332(1) \AA$ in $\left[\mathrm{W}_{2}\left(\mathrm{OCHMe}_{2}\right)_{6}(\mathrm{py})_{2}\right]$ (py = pyridine) [90]. The $\mathrm{W} 1-\mathrm{N}$ bond length of 2.270(3) $\AA$ is longer compared to the $\mathrm{W}-\mathrm{N}$ distances in $\left[\mathrm{W}_{2}\left(\mathrm{NMe}_{2}\right)_{6}\right](1.95(2)-1.99(2) \AA)[71]$ and $\left[\mathrm{W}_{2} \mathrm{Cl}_{2}\left(\mathrm{NMe}_{2}\right)_{4}\right](1.935(8)-1.937(9) \AA)$ [91]. This is attributed to the neutral nature of the $\mathrm{NHMe}_{2}$ ligand compared to the

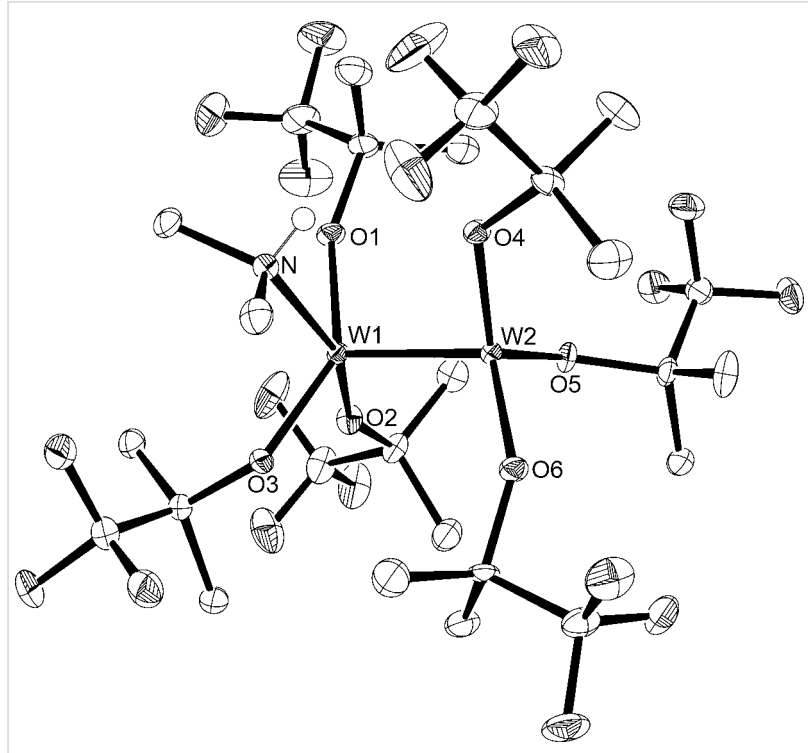

Figure 2: Molecular structure of $\mathbf{W} 2 \mathrm{~F} 3 \cdot \mathrm{NHMe}_{2}$ with thermal displacement parameters drawn at $50 \%$ probability. Hydrogen atoms are omitted for clarity.

negative $\mathrm{NMe}_{2}$ ligand and indicates a weak bond between the tungsten and the nitrogen atom. Coordination of the $\mathrm{NHMe}_{2}$ ligand to $\mathrm{W} 1$ affords markedly longer W1-O bonds (1.905(2)-1.970(2) $\AA$ ) than the W2-O bonds (1.818(2)-1.930(2) $\AA$ ). The $\mathrm{W} 1$ atom is coordinated in an almost square-pyramidal fashion $\left(\tau_{5}=0.25\right)$ [92] while the W2 atom adopts a nearly tetrahedral geometry $\left(\tau_{4}=0.89\right)$ [93], which is usually observed in $\mathrm{X}_{3} \mathrm{~W} \equiv \mathrm{WX}_{3}$ complexes $[72,83,94]$. The coordination of one amine ligand after the protonolysis of the amide ligands in $\left[\mathrm{W}_{2}\left(\mathrm{NMe}_{2}\right)_{6}\right]$ has been observed before, e.g., in $\left[\mathrm{W}_{2}(\mathrm{OAr})_{6}\left(\mathrm{HNMe}_{2}\right)\right](\mathrm{Ar}=3,5$-dimethylphenoxide $)$ [95].

Complex W2F3 $\mathrm{NHMe}_{2}$ appeared to be rather unstable especially in hexane and pentane solutions. Over a period of $24 \mathrm{~h}$, a color change from brown to bright red occurred in solution. This observation indicates the loss of the additional amine

Table 1: Selected bond lengths $[\AA]]$ and angles $\left[^{\circ}\right]$ :

\begin{tabular}{llllll} 
Bond & Bond length $[\AA]$ & Bond angle & Angle $\left[^{\circ}\right]$ & Bond angle \\
\hline W1-W2 & $2.3452(2)$ & O1-W1-O2 & $93.75(11)$ & O5-W2-O4 \\
W1-O1 & $1.905(2)$ & O1-W1-O3 & $145.01(10)$ & O1-W1-W2 & 122.91(11) \\
W1-O2 & $1.911(3)$ & O2-W1-O3 & $91.61(11)$ & O2-W1-W2 & O3-W1-W2 \\
W1-O3 & $1.970(2)$ & O1-W1-N & $82.15(11)$ & N-W1-W2 & $96.97(8)$ \\
W1-N & $2.270(3)$ & O2-W1-N & $159.81(11)$ & O4-W2-W1 \\
W2-O4 & $1.930(2)$ & O3-W1-N & $81.06(11)$ & O5-W2-W1 & $98.33(7$ \\
W2-O5 & $1.818(2)$ & O6-W2-O5 & $110.53(11)$ & O6-W2-W1
\end{tabular}


ligand, and after recrystallization from pentane at $-25{ }^{\circ} \mathrm{C}$, the red complex W2F3 was isolated. The ${ }^{1} \mathrm{H}$ NMR spectrum reveals the only expected signal at $1.51 \mathrm{ppm}$, which is in line with the previously reported values, where $\mathbf{W 2 F 3}$ had been prepared from $\left[\mathrm{NaW}_{2} \mathrm{Cl}_{7}(\mathrm{THF})_{5}\right]$ [86]. The ${ }^{13} \mathrm{C}$ and ${ }^{19} \mathrm{~F}$ NMR spectra are also consistent with literature values. Crystals of W2F3 suitable for X-ray diffraction analysis were obtained upon cooling a saturated pentane solution to $-40{ }^{\circ} \mathrm{C}$. Unfortunately, the crystal structure suffers from severe disorder. Each tungsten atom is disordered over four positions, and additionally, the alkoxide ligands are also disordered (for more details, see Supporting Information File 1). Therefore, the crystal structure only confirms the connectivity and does not allow the discussion of bond lengths and angles. This disorder pattern has been reported repeatedly for molybdenum and tungsten hexaalkoxides and silanolates [73,78,83,96-98]. An ORTEP diagram of W2F3 is displayed in Supporting Information File 1 (Scheme S13).

As stated above, R. R. Schrock could generate alkyne metathesis catalysts of type $\mathbf{V}$ (Scheme 1) from the corresponding bimetallic complex $[62,99]$. Thus, we attempted the cleavage of the $\mathrm{M} \equiv \mathrm{M}$ bond of Mo2F6 and $\mathbf{W 2 F 3}$ by an alkyne to generate the corresponding benzylidyne complexes. Unfortunately, as reported in the past by Schrock $[62,87]$, we could not achieve the selective cleavage of the triple bond in Mo2F6 by internal or terminal alkynes to isolate the corresponding alkylidyne complex. In an NMR study on the cleavage of the Mo $\equiv$ Mo triple bond, in which Mo2F6 was treated with two equivalents of 1-phenyl-1-propyne, no signals corresponding to a possible molybdenum alkylidyne complex were detected in the ${ }^{1} \mathrm{H}$ and ${ }^{19}$ F NMR spectra over a period of three days.

In contrast, the reaction of the bimetallic tungsten complex W2F3 with two equivalents of 1-phenyl-1-propyne in toluene afforded the light yellow benzylidyne complex $\mathbf{W}^{\mathbf{P h}} \mathbf{F 3}$ (Scheme 3) in satisfactory yield after recrystallization from $n$-pentane. In a metathesis-like reaction, the $\mathrm{W} \equiv \mathrm{W}$ bond is cleaved, with 2-butyne forming as a side product. Following this reaction by ${ }^{1} \mathrm{H}$ and ${ }^{19} \mathrm{~F}$ NMR spectroscopy revealed fast and selective formation of $\mathbf{W}^{\mathbf{P h}} \mathbf{F 3}$, and after 14 minutes, most of the starting material W2F3 was already consumed, with full

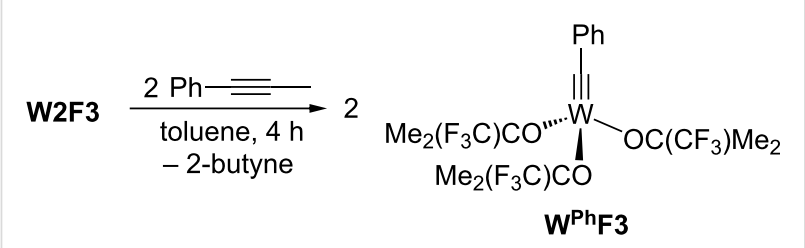

Scheme 3: Preparation of the alkylidyne complex $\mathbf{W}^{\mathrm{Ph}} \mathbf{F 3}$. conversion observed after 28 minutes. Selected ${ }^{19} \mathrm{~F}$ NMR spectra can be found in Figure S7 of Supporting Information File 1.

The ${ }^{1} \mathrm{H}$ NMR spectrum of $\mathbf{W}^{\mathbf{P h}} \mathbf{F} 3$ displays two multiplets in the aromatic region for the benzylidyne hydrogen atoms and one singlet for the methyl groups of the trifluoro-tert-butoxy ligand at $1.65 \mathrm{ppm}$. In the ${ }^{13} \mathrm{C} \mathrm{NMR}$ spectrum, the signal of the carbyne carbon atom can be found at $266.9 \mathrm{ppm}$, which is in the range typically observed for $\mathrm{RC} \equiv \mathrm{W}$ moieties [16-18,49,50,54]. The ${ }^{19} \mathrm{~F}$ NMR spectrum only exhibits one singlet for the complex with a chemical shift of $-82.4 \mathrm{ppm}$. Crystals suitable for $\mathrm{X}$-ray diffraction analysis were isolated from a saturated pentane solution at $-40{ }^{\circ} \mathrm{C}$; again, the crystal structure suffers from crystallographic problems: one alkoxide ligand is refined on two positions, while another one is refined on three positions. The crystal structure, which is displayed in Figure 3, only confirms the connectivity of this molecule, and discussion of any bond length is not meaningful (for more details, see Supporting Information File 1). A similar crystal structure with the 2,4,6-trimethylbenzylidyne moiety at the tungsten atom, which does not exhibit disorder, has been reported previously [54].

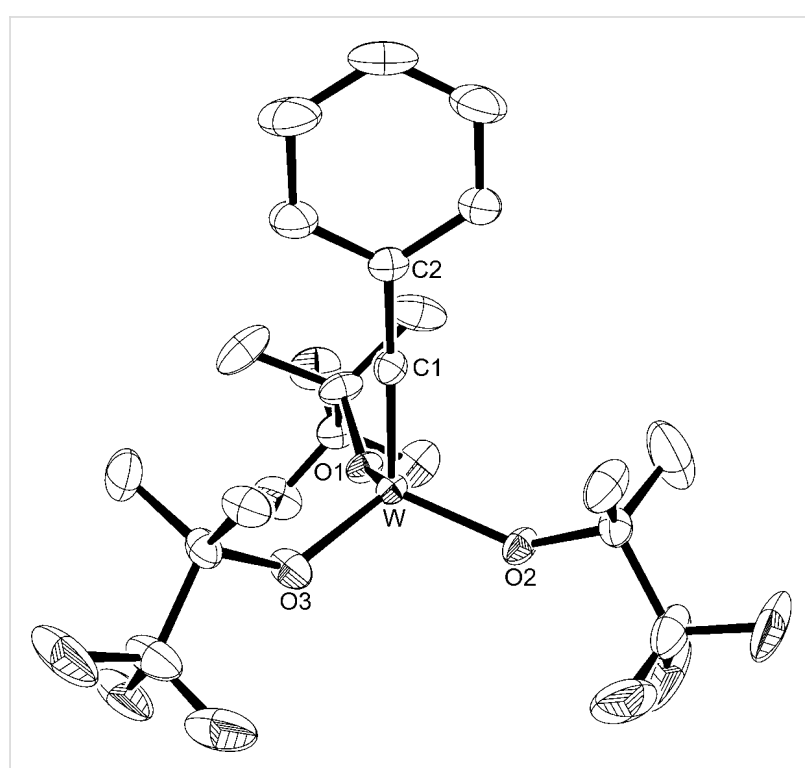

Figure 3: Molecular structure of $\mathbf{W}^{\mathbf{P h}} \mathbf{F} 3$ with thermal displacement parameters drawn at $50 \%$ probability. Hydrogen atoms and minor components of the disordered $\mathrm{OC}\left(\mathrm{CF}_{3}\right) \mathrm{Me}_{2}$ groups are omitted for clarity.

\section{Catalytic studies}

With the bimetallic complexes Mo2F6 and W2F3 and the new alkylidyne complex $\mathbf{W}^{\mathbf{P h}} \mathbf{F 3}$ at hand, we aimed at systematically investigating the catalytic activity of those complexes. Even though we failed in selectively cleaving the $\mathrm{Mo} \equiv$ Mo triple bond, we attempted catalytic alkyne metathesis with Mo2F6. Interestingly, a marginal catalytic activity could be detected for complex Mo2F6: over the course of four days, the dimolyb- 
denum complex achieved a conversion of $70 \%$ in the self-metathesis of the standard substrate 3-pentynyl benzyl ether in toluene in the presence of molecular sieves (MS $5 \AA$ ) as 2-butyne scavenger. The conversion versus time diagram (Supporting Information File 1, Figure S8) exhibits a sigmoidal curve progression, which indicates the slow formation of a catalytically active species, presumably an alkylidyne complex, despite our inability to monitor the formation of such a species by NMR spectroscopy. We attribute the poor catalytic performance of Mo2F6 to the low solubility in all common solvents [73], since most of the compound still remained undissolved in the reaction mixture after four days. However, all efforts to optimize the metathesis conditions and to achieve higher conversions failed. Attempts to increase the solubility of Mo2F6 in toluene by performing the metathesis reaction at $60^{\circ} \mathrm{C}$ led to no detectable conversion of the starting material. Furthermore, catalysis in $\mathrm{CH}_{2} \mathrm{Cl}_{2}$ afforded even lower conversions compared to toluene, while the metathesis failed completely in diethyl ether.

For the potential tungsten catalysts, toluene solutions of 1-phenyl-1-propyne were treated with W2F3 $(0.5 \mathrm{~mol} \%)$ and $\mathbf{W}^{\mathbf{P h}} \mathbf{F 3}(1 \mathrm{~mol} \%)$ and stirred in the presence of molecular sieves (MS $5 \AA$ ) as 2-butyne scavenger and $n$-decane as internal standard at room temperature (Scheme 4). The catalysis was initially monitored over time through gas chromatography, affording the conversion versus time diagram depicted in Figure 4

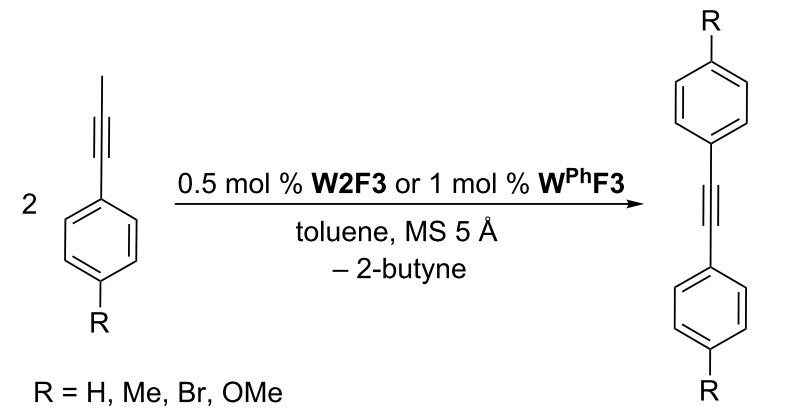

Scheme 4: Self-metathesis of 1-phenyl-1-propyne derivatives by tungsten complexes $\mathbf{W} 2 \mathrm{~F} 3$ and $\mathbf{W}^{\mathbf{P h}} \mathbf{F} 3$.

Figure 4 clearly shows that both tungsten complexes are active in the metathesis of 1-phenyl-1-propyne, with the bimetallic compound W2F3 (grey) showing a slower initiation rate compared to the alkylidyne complex $\mathbf{W}^{\mathbf{P h}} \mathbf{F 3}$. For the bimetallic complex W2F3, an additional initiation step is required, in which the $\mathrm{W} \equiv \mathrm{W}$ triple bond is cleaved and catalytically active alkylidyne species are formed. Therefore, the conversion of the substrate with catalyst W2F3 is significantly slower at the beginning of the reaction. The initial catalyst turnover frequen-

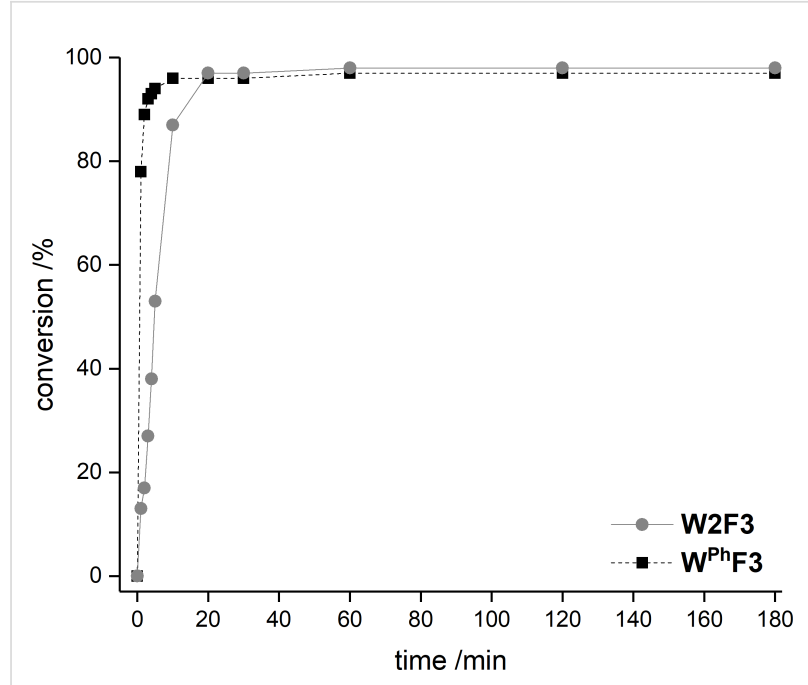

Figure 4: Conversion versus time diagram for the self-metathesis of 1-phenyl-1-propyne catalyzed by $0.5 \mathrm{~mol} \% \mathbf{W} 2 \mathrm{~F} 3$ (grey) and $1 \mathrm{~mol} \%$ W $^{\mathrm{Ph}} \mathrm{F3}$ (black).

cies were calculated from the conversion of 1-phenyl-1-propyne after one minute $\left(\mathrm{TOF}_{1 \mathrm{~min}}\right)$. The TOF of the alkylidyne complex $\mathbf{W}^{\mathbf{P h}} \mathbf{F 3}$ reaches $78 \mathrm{~min}^{-1}\left(1.30 \mathrm{~s}^{-1}\right)$, while $\mathbf{W} \mathbf{2 F 3}$ has a significantly lower TOF of $13 \mathrm{~min}^{-1}\left(0.21 \mathrm{~s}^{-1}\right)$ after one minute; this value is based on the formation of two catalytically active alkylidyne species upon treatment with the alkyne substrate. After 10 minutes, the alkylidyne complex $\mathbf{W}^{\mathbf{P h}} \mathbf{F 3}$ has accomplished nearly full conversion and after 20 minutes, catalyst W2F3 achieves the same conversion of the starting material. The maximum conversion of around $97 \%$ is reached for both catalysts within 60 minutes. Accordingly, we aimed at further monitoring the substrate scope of the complexes including the metathesis of terminal alkynes as well as ring-closing alkyne metathesis (RCAM).

Table 2 summarizes the isolated yields for various self-metathesis and RCAM reactions. These findings are in line with our initial results regarding the conversion of 1-phenyl-1-propyne (Table 2, entry 1). Both tungsten complexes afforded excellent yields in the metathesis of different para-substituted phenylpropynes (Table 2, entries 2-4). For both catalysts, the yields are identical within the error of the experiment. Furthermore, the well-established substrates 3-pentynyl $(\mathrm{R}=\mathrm{Me})$ and 3-butynyl $(\mathrm{R}=\mathrm{H})$ benzyl ether (Table 2, entry 5) and 3-pentynyl $(\mathrm{R}=\mathrm{Me})$ and 3-butynyl $(\mathrm{R}=\mathrm{H})$ benzyl ester (Table 2, entry 6) afforded good isolated yields. The bimetallic complex W2F3 is even capable of metathesizing terminal alkynes at room temperature and performs in the same manner as the alkylidyne complex $\mathbf{W}^{\mathbf{P h}} \mathbf{F 3}$. Additional conversion versus time diagrams are displayed in Figures S9 and S10 in Supporting Information File 1. Finally, the ditungsten catalyst 


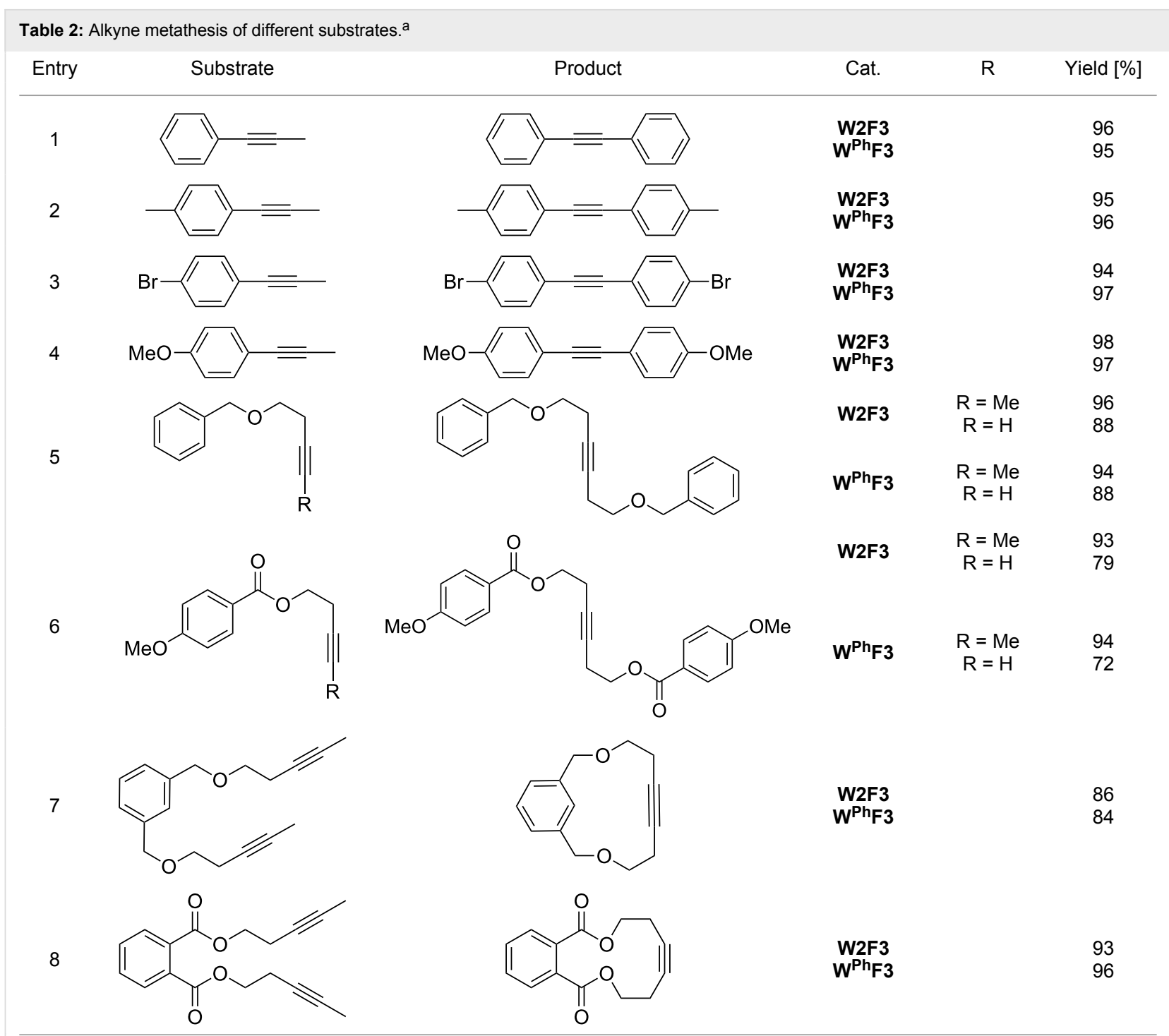

aSelf-metathesis: substrate $(0.5 \mathrm{mmol})$, catalyst $\left(0.5 \mathrm{~mol} \% \mathbf{W} \mathbf{F 3} ; 1 \mathrm{~mol} \% \mathbf{W}^{\mathrm{Ph}} \mathbf{F 3}\right)$, toluene (internal alkynes: $2.5 \mathrm{~mL}, 200 \mathrm{mM}$; terminal alkynes: $24 \mathrm{~mL}, 21 \mathrm{mM})$, MS $5 \AA$ (500 mg), $25^{\circ} \mathrm{C}, 2 \mathrm{~h}$. RCAM: substrate $(0.5 \mathrm{mmol})$, catalyst ( $\left.1 \mathrm{~mol} \% \mathbf{W} 2 \mathrm{~F} 3 ; 2 \mathrm{~mol} \% \mathbf{W}^{\text {Ph}} \mathrm{F} 3\right)$, toluene $(24 \mathrm{~mL}, 21 \mathrm{mM})$, MS $5 \AA(1.0 \mathrm{~g}), 25^{\circ} \mathrm{C}, 2 \mathrm{~h}$.

W2F3 was also employed in alkyne cross-metathesis (ACM), a reaction which is of large interest for the application of alkyne metathesis, but often leads to product mixtures. Therefore, (trimethylsilyl)propyne and (trimethylsilyl)acetylene were chosen as reaction partners in ACM, since this reaction proved to be quite efficient in the past $[25,54,100]$. A toluene solution of both substrates (1:2 ratio, TMS-alkyne in excess) was charged with the catalyst W2F3 $(0.5-1 \mathrm{~mol} \%)$ in the presence of molecular sieves $5 \AA$ and stirred for two hours at room temperature. The isolated yields of the ACM are summarized in Table 3. The depicted reactions selectively afforded the unsymmetrical alkynes, corroborating that the bimetallic tungsten complex W2F3 is able to introduce a trimethylsilyl protecting group to alkynes.

\section{Conclusion}

Previously, we have reported the optimum level of fluorination in MoF6 and WF3 as the most catalytically active alkylidyne complexes [54]. Thus, we intended to study the catalytic activity of the well-known bimetallic molybdenum and tungsten complexes bearing the same fluoroalkoxide ligands. Indeed, W2F3 as the bimetallic analogue to mononuclear WF3 is highly active in the metathesis of internal and even terminal alkynes and also promotes alkyne cross-metathesis efficiently. The Mo2F6 complex, however, does not exhibit satisfactory alkyne metathesis activity, which we attribute to its low solubility. Furthermore, the corresponding mononuclear benzylidyne complex $\mathbf{W}^{\mathbf{P h}} \mathbf{F 3}$ is easily accessible from the dinuclear W2F3 complex and performs equally well compared to the latter. 


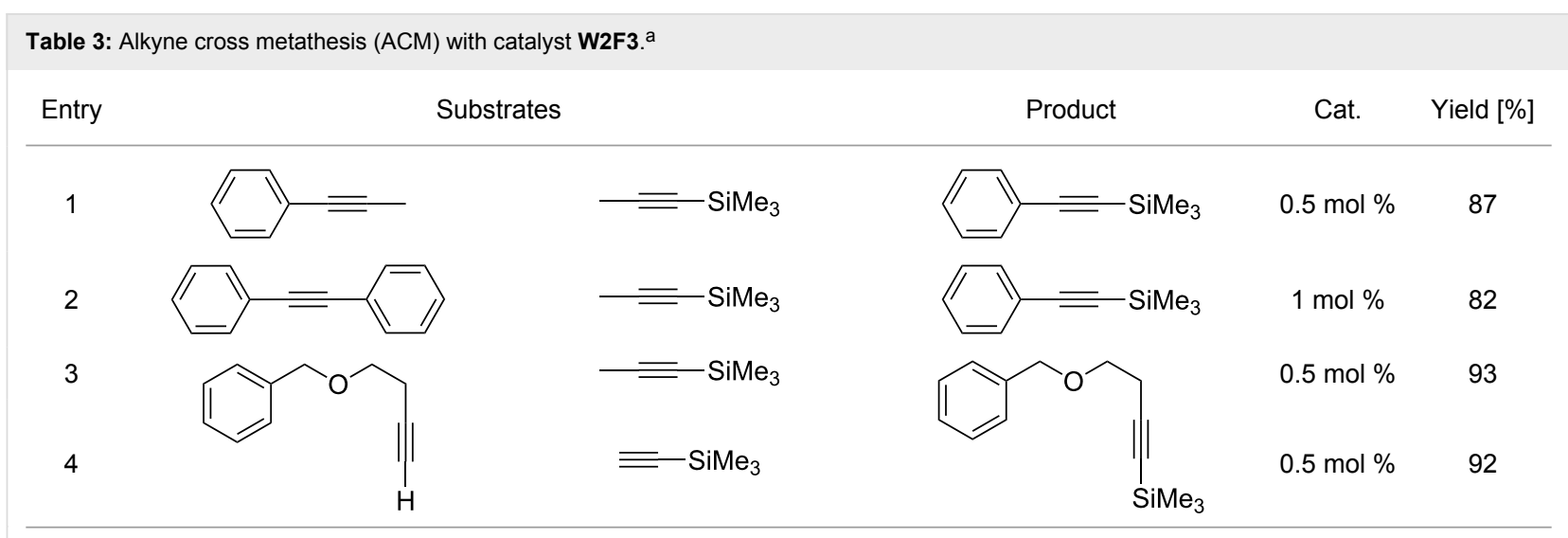

aSubstrate $(0.5 \mathrm{mmol})$, TMS-propyne or TMS-acetylene (1 mmol), toluene (internal alkynes: $2.5 \mathrm{~mL}$, terminal alkynes: $24 \mathrm{~mL}), \mathrm{MS} 5 \AA$ (500 mg), $25^{\circ} \mathrm{C}, 2 \mathrm{~h}$.

The finding that W2F3 is a highly active alkyne metathesis precatalyst and does not have to be converted into an alkylidyne species prior to catalysis could be beneficial for future applications of alkyne metathesis since this protocol represents a convenient approach to alkyne metathesis catalysts in two steps starting from $\mathrm{WCl}_{4}$.

\section{Supporting Information}

CCDC 1850924-1850926 contain the supplementary crystallographic data for this paper. These data can be obtained free of charge via http://www.ccdc.cam.ac.uk/data_request/cif.

\section{Supporting Information File 1}

Experimental section, NMR spectra, catalysis procedure and product characterization, crystallographic details for W2F3. $\left(\mathrm{NHMe}_{2}\right)$, W2F3 and $\mathbf{W}^{\mathbf{P h}} \mathbf{F 3}$. [https://www.beilstein-journals.org/bjoc/content/ supplementary/1860-5397-14-220-S1.pdf]

\section{Acknowledgements}

H.E. wishes to thank the Fonds der Chemischen Industrie (FCI) for a Chemiefonds Fellowship. This work was funded by the Deutsche Forschungsgemeinschaft (DFG) through project TA 189/12-1 ("Mechanistic studies on the catalytic metathesis of internal and terminal alkynes and diynes"). The authors wish to thank Dr. M. Freytag for the crystal structure determination of W2F3 $\left(\mathrm{NHMe}_{2}\right)$.

\section{ORCID ${ }^{\circledR}$ iDs}

Dirk Bockfeld - https://orcid.org/0000-0003-1084-8577 Matthias Tamm - https://orcid.org/0000-0002-5364-0357

\section{References}

1. Fürstner, A. Angew. Chem., Int. Ed. 2000, 39, 3012-3043. doi:10.1002/1521-3773(20000901)39:17<3012::aid-anie3012>3.3.co; 2-7

2. Connon, S. J.; Blechert, S. Angew. Chem., Int. Ed. 2003, 42, 1900-1923. doi:10.1002/anie.200200556

3. Grela, K. Olefin Metathesis; John Wiley \& Sons: Hoboken, NJ, U.S.A., 2014. doi:10.1002/9781118711613

4. Hoveyda, A. H.; Zhugralin, A. R. Nature 2007, 450, 243-251. doi:10.1038/nature06351

5. Grubbs, R. H.; Wenzel, A. G.; O'Leary, D. J.; Khosravi, E., Eds. Handbook of Metathesis; Wiley-VCH Verlag GmbH: Weinheim, Germany, 2015. doi:10.1002/9783527674107

6. Fürstner, A.; Davies, P. W. Chem. Commun. 2005, 2307-2320. doi:10.1039/b419143a

7. Mortreux, A.; Coutelier, O. J. Mol. Catal. A: Chem. 2006, 254, 96-104 doi:10.1016/j.molcata.2006.03.054

8. Zhang, W.; Moore, J. S. Adv. Synth. Catal. 2007, 349, 93-120. doi:10.1002/adsc.200600476

9. Wu, X.; Tamm, M. Beilstein J. Org. Chem. 2011, 7, 82-93. doi:10.3762/bjoc.7.12

10. Fürstner, A. Angew. Chem., Int. Ed. 2013, 52, 2794-2819. doi:10.1002/anie.201204513

11. Yang, H.; Jin, Y.; Du, Y.; Zhang, W. J. Mater. Chem. A 2014, 2, 5986-5993. doi:10.1039/c3ta14227b

12. Katz, T. J.; McGinnis, J. J. Am. Chem. Soc. 1975, 97, 1592-1594. doi:10.1021/ja00839a063

13. Schrock, R. R.; Hoveyda, A. H. Angew. Chem., Int. Ed. 2003, 42, 4592-4633. doi:10.1002/anie.200300576

14. Schrock, R. R.; Czekelius, C. Adv. Synth. Catal. 2007, 349, 55-77. doi:10.1002/adsc.200600459

15. Cortez, G. A.; Schrock, R. R.; Hoveyda, A. H. Angew. Chem., Int. Ed. 2007, 46, 4534-4538. doi:10.1002/anie.200605130

16. Beer, S.; Hrib, C. G.; Jones, P. G.; Brandhorst, K.; Grunenberg, J.; Tamm, M. Angew. Chem., Int. Ed. 2007, 46, 8890-8894. doi:10.1002/anie.200703184

17. Beer, S.; Brandhorst, K.; Hrib, C. G.; Wu, X.; Haberlag, B.; Grunenberg, J.; Jones, P. G.; Tamm, M. Organometallics 2009, 28, 1534-1545. doi:10.1021/om801119t 
18. Haberlag, B.; Wu, X.; Brandhorst, K.; Grunenberg, J.; Daniliuc, C. G.; Jones, P. G.; Tamm, M. Chem. - Eur. J. 2010, 16, 8868-8877. doi:10.1002/chem.201000597

19. Lysenko, S.; Haberlag, B.; Daniliuc, C. G.; Jones, P. G.; Tamm, M. ChemCatChem 2011, 3, 115-118. doi:10.1002/cctc.201000355

20. Lysenko, S.; Daniliuc, C. G.; Jones, P. G.; Tamm, M. J. Organomet. Chem. 2013, 744, 7-14. doi:10.1016/j.jorganchem.2013.03.035

21. Clark, D. N.; Schrock, R. R. J. Am. Chem. Soc. 1978, 100, 6774-6776. doi:10.1021/ja00489a049

22. Schrock, R. R.; Clark, D. N.; Sancho, J.; Wengrovius, J. H.; Rocklage, S. M.; Pedersen, S. F. Organometallics 1982, 1, 1645-1651. doi:10.1021/om00072a018

23. Heppekausen, J.; Stade, R.; Goddard, R.; Fürstner, A. J. Am. Chem. Soc. 2010, 132, 11045-11057. doi:10.1021/ja104800w

24. Heppekausen, J.; Stade, R.; Kondoh, A.; Seidel, G.; Goddard, R.; Fürstner, A. Chem. - Eur. J. 2012, 18, 10281-10299. doi:10.1002/chem.201200621

25. Persich, P.; Llaveria, J.; Lhermet, R.; de Haro, T.; Stade, R.; Kondoh, A.; Fürstner, A. Chem. - Eur. J. 2013, 19, 13047-13058. doi:10.1002/chem.201302320

26. Willwacher, J.; Heggen, B.; Wirtz, C.; Thiel, W.; Fürstner, A. Chem. - Eur. J. 2015, 21, 10416-10430 doi:10.1002/chem.201501491

27. Schaubach, S.; Gebauer, K.; Ungeheuer, F.; Hoffmeister, L.; Ilg, M. K.; Wirtz, C.; Fürstner, A. Chem. - Eur. J. 2016, 22, 8494-8507. doi:10.1002/chem.201601163

28. Lysenko, S.; Volbeda, J.; Jones, P. G.; Tamm, M. Angew. Chem., Int. Ed. 2012, 51, 6757-6761. doi:10.1002/anie.201202101

29. Li, S. T.; Schnabel, T.; Lysenko, S.; Brandhorst, K.; Tamm, M. Chem. Commun. 2013, 49, 7189-7191. doi:10.1039/c3cc43108h

30. Tamm, M.; Schnabel, T.; Melcher, D.; Brandhorst, K.; Bockfeld, D. Chem. - Eur. J. 2018, 24, 9022-9032. doi:10.1002/chem.201801651

31. Jyothish, K.; Zhang, W. Angew. Chem., Int. Ed. 2011, 50, 3435-3438. doi:10.1002/anie.201007559

32. Jyothish, K.; Wang, Q.; Zhang, W. Adv. Synth. Catal. 2012, 354 , 2073-2078. doi:10.1002/adsc.201200243

33. Yang, H.; Liu, Z.; Zhang, W. Adv. Synth. Catal. 2013, 355, 885-890. doi:10.1002/adsc.201201105

34. Du, Y.; Yang, H.; Zhu, C.; Ortiz, M.; Okochi, K. D.; Shoemaker, R.; Jin, Y.; Zhang, W. Chem. - Eur. J. 2016, 22, 7959-7963. doi:10.1002/chem.201505174

35. Hu, K.; Yang, H.; Zhang, W.; Qin, Y. Chem. Sci. 2013, 4, 3649-3653. doi:10.1039/c3sc51264a

36. Yang, H.; Zhu, Y.; Du, Y.; Tan, D.; Jin, Y.; Zhang, W. Mater. Chem. Front. 2017, 1, 1369-1372. doi:10.1039/c6qm00359a

37. Zhang, C.; Wang, Q.; Long, H.; Zhang, W. J. Am. Chem. Soc. 2011, 133, 20995-21001. doi:10.1021/ja210418t

38. Wang, Q.; Zhang, C.; Noll, B. C.; Long, H.; Jin, Y.; Zhang, W. Angew. Chem., Int. Ed. 2014, 53, 10663-10667. doi:10.1002/anie.201404880

39. Wang, Q.; Yu, C.; Long, H.; Du, Y.; Jin, Y.; Zhang, W Angew. Chem., Int. Ed. 2015, 54, 7550-7554. doi:10.1002/anie.201501679

40. Yu, C.; Long, H.; Jin, Y.; Zhang, W. Org. Lett. 2016, 18, 2946-2949. doi:10.1021/acs.orglett.6b01293

41. Wang, Q.; Yu, C.; Zhang, C.; Long, H.; Azarnoush, S.; Jin, Y.; Zhang, W. Chem. Sci. 2016, 7, 3370-3376. doi:10.1039/c5sc04977f
42. Ortiz, M.; Cho, S.; Niklas, J.; Kim, S.; Poluektov, O. G.; Zhang, W.; Rumbles, G.; Park, J. J. Am. Chem. Soc. 2017, 139, 4286-4289. doi:10.1021/jacs.7b00220

43. Ortiz, M.; Yu, C.; Jin, Y.; Zhang, W. Top. Curr. Chem. 2017, 375, 69. doi:10.1007/s41061-017-0156-1

44. Paley, D. W.; Sedbrook, D. F.; Decatur, J.; Fischer, F. R.; Steigerwald, M. L.; Nuckolls, C. Angew. Chem., Int. Ed. 2013, 52, 4591-4594. doi:10.1002/anie.201300758

45. Bellone, D. E.; Bours, J.; Menke, E. H.; Fischer, F. R. J. Am. Chem. Soc. 2015, 137, 850-856. doi:10.1021/ja510919v

46. von Kugelgen, S.; Bellone, D. E.; Cloke, R. R.; Perkins, W. S.; Fischer, F. R. J. Am. Chem. Soc. 2016, 138, 6234-6239. doi:10.1021/jacs.6b02422

47. von Kugelgen, S.; Sifri, R.; Bellone, D.; Fischer, F. R. J. Am. Chem. Soc. 2017, 139, 7577-7585. doi:10.1021/jacs.7b02225

48. Jeong, H.; von Kugelgen, S.; Bellone, D.; Fischer, F. R. J. Am. Chem. Soc. 2017, 139, 15509-15514. doi:10.1021/jacs.7b09390

49. Haberlag, B.; Freytag, M.; Daniliuc, C. G.; Jones, P. G.; Tamm, M. Angew. Chem., Int. Ed. 2012, 51, 13019-13022. doi:10.1002/anie.201207772

50. Haberlag, B.; Freytag, M.; Jones, P. G.; Tamm, M. Adv. Synth. Catal. 2014, 356, 1255-1265. doi:10.1002/adsc.201400051

51. Hötling, S.; Bittner, C.; Tamm, M.; Dähn, S.; Collatz, J.; Steidle, J. L. M.; Schulz, S. Org. Lett. 2015, 17, 5004-5007. doi:10.1021/acs.orglett.5b02461

52. Estes, D. P.; Bittner, C.; Àrias, Ò.; Casey, M.; Fedorov, A.; Tamm, M.; Copéret, C. Angew. Chem., Int. Ed. 2016, 55, 13960-13964. doi:10.1002/anie.201605129

53. Estes, D. P.; Gordon, C. P.; Fedorov, A.; Liao, W.-C.; Ehrhorn, H.; Bittner, C.; Zier, M. L.; Bockfeld, D.; Chan, K. W.; Eisenstein, O.; Raynaud, C.; Tamm, M.; Copéret, C. J. Am. Chem. Soc. 2017, 139, 17597-17607. doi:10.1021/jacs.7b09934

54. Bittner, C.; Ehrhorn, H.; Bockfeld, D.; Brandhorst, K.; Tamm, M. Organometallics 2017, 36, 3398-3406. doi:10.1021/acs.organomet.7b00519

55. Freudenberger, J. H.; Schrock, R. R.; Churchill, M. R.; Rheingold, A. L.; Ziller, J. W. Organometallics 1984, 3, 1563-1573. doi:10.1021/om00088a019

56. Buhro, W. E.; Chisholm, M. H. Adv. Organomet. Chem. 1987, 27 , 311-369. doi:10.1016/s0065-3055(08)60030-1

57. Schrock, R. R. Chem. Rev. 2002, 102, 145-180. doi:10.1021/cr0103726

58. Wengrovius, J. H.; Sancho, J.; Schrock, R. R. J. Am. Chem. Soc. 1981, 103, 3932-3934. doi:10.1021/ja00403a058

59. Schrock, R. R. J. Organomet. Chem. 1986, 300, 249-262. doi:10.1016/0022-328x(86)84064-5

60. Bray, A.; Mortreux, A.; Petit, F.; Petit, M.; Szymanska-Buzar, T. J. Chem. Soc., Chem. Commun. 1993, 197-199. doi:10.1039/c39930000197

61. Coutelier, O.; Mortreux, A. Adv. Synth. Catal. 2006, 348, 2038-2042. doi:10.1002/adsc.200606116

62. Listemann, M. L.; Schrock, R. R. Organometallics 1985, 4, 74-83. doi:10.1021/om00120a014

63. Fürstner, A.; Seidel, G. Angew. Chem., Int. Ed. 1998, 37, 1734-1736. doi:10.1002/(sici)1521-3773(19980703)37:12<1734::aid-anie1734>3.0 .co;2-6

64. Nicolaou, K. C.; Bulger, P. G.; Sarlah, D. Angew. Chem., Int. Ed. 2005, 44, 4490-4527. doi:10.1002/anie.200500369 
65. McCullough, L. G.; Listemann, M. L.; Schrock, R. R.; Churchill, M. R.; Ziller, J. W. J. Am. Chem. Soc. 1983, 105, 6729-6730. doi:10.1021/ja00360a040

66. Freudenberger, J. H.; Schrock, R. R. Organometallics 1986, 5, 1411-1417. doi:10.1021/om00138a019

67. Mortreux, A.; Petit, F.; Petit, M.; Szymanska-Buzar, T. J. Mol. Catal. A: Chem. 1995, 96, 95-105. doi:10.1016/1381-1169(94)00004-2

68. Coutelier, O.; Nowogrocki, G.; Paul, J.-F.; Mortreux, A. Adv. Synth. Catal. 2007, 349, 2259-2263. doi:10.1002/adsc.200700104

69. Chisholm, M. H.; Cotton, F. A. Acc. Chem. Res. 1978, 11, 356-362. doi:10.1021/ar50129a006

70. Chisholm, M. H.; Cotton, F. A.; Frenz, B. A.; Reichert, W. W.; Shive, L. W.; Stults, B. R. J. Am. Chem. Soc. 1976, 98, 4469-4476. doi:10.1021/ja00431a024

71. Chisholm, M. H.; Cotton, F. A.; Extine, M.; Stults, B. R. J. Am. Chem. Soc. 1976, 98, 4477-4485. doi:10.1021/ja00431a025

72. Coffindaffer, T. W.; Rothwell, I. P.; Huffmann, J. C. Inorg. Chem. 1985, 24, 1643-1646. doi:10.1021/ic00205a010

73. Gilbert, T. M.; Landes, A. M.; Rogers, R. D. Inorg. Chem. 1992, 31, 3438-3444. doi:10.1021/ic00042a020

74. Su, K.; Tilley, T. D. Chem. Mater. 1997, 9, 588-595. doi:10.1021/cm960413s

75. Chisholm, M. H.; Folting, K.; Wu, D.-D. Chem. Commun. 1998, 379-380. doi:10.1039/a708268a

76. Radius, U.; Attner, J. Eur. J. Inorg. Chem. 1998, 299-303. doi:10.1002/(sici)1099-0682(199803)1998:3<299::aid-ejic299>3.0.co; 2-q

77. Budzichowski, T. A.; Chisholm, M. H.; Tiedtke, D. B.; Gruhn, N. E.; Lichtenberger, D. L. Polyhedron 1998, 17, 705-711. doi:10.1016/s0277-5387(97)00360-4

78. Gilbert, T. M.; Bauer, C. B.; Bond, A. H.; Rogers, R. D. Polyhedron 1999, 18, 1293-1301. doi:10.1016/s0277-5387(98)00433-1

79. Chetcuti, M. J.; Chisholm, M. H.; Huffman, J. C.; Leonelli, J J. Am. Chem. Soc. 1983, 105, 292-293. doi:10.1021/ja00340a025

80. Chisholm, M. H.; Huffman, J. C.; Ratermann, A. L. Inorg. Chem. 1983, 22, 4100-4105. doi:10.1021/ic00168a055

81. Chisholm, M. H.; Conroy, B. K.; Eichhorn, B. W.; Folting, K.; Hoffman, D. M.; Huffman, J. C.; Marchant, N. S. Polyhedron 1987, 6, 783-792. doi:10.1016/s0277-5387(00)86884-9

82. Chisholm, M. H.; Eichhorn, B. W.; Folting, K.; Huffman, J. C.; Ontiveros, C. D.; Streib, W. E.; van der Sluys, W. G. Inorg. Chem. 1987, 26, 3182-3186. doi:10.1021/ic00266a024

83. Chisholm, M. H.; Cook, C. M.; Huffman, J. C.; Streib, W. E. J. Chem. Soc., Dalton Trans. 1991, 929-937. doi:10.1039/dt9910000929

84. Chisholm, M. H.; Huang, J.-H.; Huffman, J. C.; Parkin, I. P. Inorg. Chem. 1997, 36, 1642-1651. doi:10.1021/ic961429n

85. Budzichowski, T. A.; Chisholm, M. H.; Folting, K.; Huffman, J. C.; Streib, W. E.; Tiedtke, D. B. Polyhedron 1998, 17, 857-867. doi:10.1016/s0277-5387(97)00290-8

86. Girolami, G. S.; Sattelberger, A. P., Eds. Inorganic Syntheses: Volume 36; Inorganic Syntheses; John Wiley \& Sons, Inc.: Hoboken, NJ, U.S.A., 2014. doi:10.1002/9781118744994

87. Strutz, H.; Schrock, R. R. Organometallics 1984, 3, 1600-1601. doi:10.1021/om00088a030

88. Fackler, J. P., Ed. Inorganic syntheses; Wiley: New York, NY, U.S.A., 1982; Vol. 21. doi:10.1002/9780470132524
89. Budzichowski, T. A.; Chisholm, M. H.; Tiedtke, D. B.; Huffman, J. C.; Streib, W. E. Organometallics 1995, 14, 2318-2324. doi:10.1021/om00005a033

90. Akiyama, M.; Chisholm, M. H.; Cotton, F. A.; Extine, M. W.; Haitko, D. A.; Little, D.; Fanwick, P. E. Inorg. Chem. 1979, 18, 2266-2270. doi:10.1021/ic50198a043

91. Chisholm, M. H.; Cotton, F. A.; Extine, M.; Millar, M.; Stults, B. R. J. Am. Chem. Soc. 1976, 98, 4486-4491. doi:10.1021/ja00431a026

92. Addison, A. W.; Rao, T. N.; Reedijk, J.; van Rijn, J.; Verschoor, G. C. J. Chem. Soc., Dalton Trans. 1984, 1349-1356. doi:10.1039/dt9840001349

93. Yang, L.; Powell, D. R.; Houser, R. P. Dalton Trans. 2007, 955-964. doi:10.1039/b617136b

94. Chisholm, M. H.; Parkin, I. P.; Huffman, J. C.; Lobkovsky, E. M.; Folting, K. Polyhedron 1991, 10, 2839-2846. doi:10.1016/s0277-5387(00)86188-4

95. Coffindaffer, T. W.; Niccolai, G. P.; Powell, D.; Rothwell, I. P. J. Am. Chem. Soc. 1985, 107, 3572-3583. doi:10.1021/ja00298a029

96. Chisholm, M. H.; Folting, K.; Hampden-Smith, M.; Smith, C. A. Polyhedron 1987, 6, 1747-1755. doi:10.1016/s0277-5387(00)86546-8

97. Cayton, R. H.; Chisholm, M. H. Inorg. Chem. 1991, 30, 1422-1425. doi:10.1021/ic00006a051

98. Chisholm, M. H.; Gallucci, J. C.; Hollandsworth, C. B. Polyhedron 2006, 25, 827-833. doi:10.1016/j.poly.2005.07.010

99. Schrock, R. R.; Listemann, M. L.; Sturgeoff, L. G. J. Am. Chem. Soc. 1982, 104, 4291-4293. doi:10.1021/ja00379a061

100.Lhermet, R.; Fürstner, A. Chem. - Eur. J. 2014, 20, 13188-13193. doi:10.1002/chem.201404166

\section{License and Terms}

This is an Open Access article under the terms of the Creative Commons Attribution License (http://creativecommons.org/licenses/by/4.0). Please note that the reuse, redistribution and reproduction in particular requires that the authors and source are credited.

The license is subject to the Beilstein Journal of Organic Chemistry terms and conditions:

(https://www.beilstein-journals.org/bjoc)

The definitive version of this article is the electronic one which can be found at: doi:10.3762/bjoc. 14.220 